\title{
Examining post-fire vegetation recovery with Landsat time series analysis in three western North American forest types
}

\author{
Benjamin C. Bright ${ }^{1 *} \mathbb{D}$, Andrew T. Hudak', Robert E. Kennedy ${ }^{2}$, Justin D. Braaten² and Azad Henareh Khalyani ${ }^{3}$
}

\begin{abstract}
Background: Few studies have examined post-fire vegetation recovery in temperate forest ecosystems with Landsat time series analysis. We analyzed time series of Normalized Burn Ratio (NBR) derived from LandTrendr spectral-temporal segmentation fitting to examine post-fire NBR recovery for several wildfires that occurred in three different coniferous forest types in western North America during the years 2000 to 2007. We summarized NBR recovery trends, and investigated the influence of burn severity, post-fire climate, and topography on post-fire vegetation recovery via random forest (RF) analysis.

Results: NBR recovery across forest types averaged 30 to $44 \%$ five years post fire, 47 to $72 \%$ ten years post fire, and 54 to $77 \% 13$ years post fire, and varied by time since fire, severity, and forest type. Recovery rates were generally greatest for several years following fire. Recovery in terms of percent NBR was often greater for higher-severity patches. Recovery rates varied between forest types, with conifer-oak-chaparral showing the greatest NBR recovery rates, mixed conifer showing intermediate rates, and ponderosa pine showing slowest rates. Between 1 and 28\% of patches had recovered to pre-fire NBR levels 9 to 16 years after fire, with greater percentages of low-severity patches showing full NBR recovery.

Precipitation decreased and temperatures generally remained the same or increased post fire. Pre-fire NBR and burn severity were important predictors of NBR recovery for all forest types, and explained 2 to $6 \%$ of the variation in post-fire NBR recovery. Post-fire climate anomalies were also important predictors of NBR recovery and explained an additional 30 to $41 \%$ of the variation in post-fire NBR recovery.

Conclusions: Landsat time series analysis was a useful means of describing and analyzing post-fire vegetation recovery across mixed-severity wildfire extents. We demonstrated that a relationship exists between post-fire vegetation recovery and climate in temperate ecosystems of western North America. Our methods could be applied to other burned landscapes for which spatially explicit measurements of post-fire vegetation recovery are needed.
\end{abstract}

Keywords: burn severity, climate, fire, forest, landsat, North America, satellite imagery, time series, vegetation recovery

\footnotetext{
* Correspondence: benjamincbright@fs.fed.us

${ }^{1}$ USDA Forest Service, Rocky Mountain Research Station, 1221 S. Main Street,

Moscow, Idaho 83843, USA

Full list of author information is available at the end of the article
} 


\section{Resumen}

Antecedentes: Pocos estudios han examinado la recuperación post-fuego de la vegetación en ecosistemas de bosques templados mediante el análisis de series temporales de imágenes Landsat. Analizamos series temporales de la Relación de Quemas Normalizadas (NBR) derivadas del ajuste de la segmentación espectro-temporal de LandTrendr para examinar la recuperación post-fuego de la NBR para diferentes incendios ocurridos en tres tipos de bosques de coníferas en el oeste de Norte América durante los años 2000 a 2007. Resumimos las tendencias de la NBR e investigamos la influencia de la severidad de los incendios, el clima post-fuego y la topografía en la recuperación post-fuego de la vegetación a través del análisis de bosques al azar (RF).

Resultados: La recuperación de la NBR entre los tipos forestales promedió del 30 al 44 \% cinco años post fuego, de 47 a $72 \%$ diez años post fuego, y de 54 al 77\% 13 años post fuego y variaron por el tiempo desde el incendio, la severidad de cada fuego y el tipo forestal. La tasa de recuperación fue generalmente más grande después de muchos años de ocurrido los incendios. La recuperación en términos de porcentaje la NBR fue frecuentemente mayor para los parches quemados con alta severidad. Las tasas de recuperación variaron entre tipos forestales, en las que el tipo conífera-roble-chaparral mostró las tasas más altas de recuperación de la NBR, siendo intermedias para el tipo de coníferas mixtas, y las más lentas para el tipo pino ponderosa. Entre el 1 y el $28 \%$ de los parches se habían recuperado a niveles de NBR pre fuego entre 9 y 16 años del post fuego, con los mayores porcentajes de parches de baja severidad mostrando la más alta recuperación de la NBR. Las precipitaciones decrecieron y las temperaturas permanecieron iguales o aumentaron durante el post fuego. La NBR previa a los incendios y la severidad del fuego fueron importantes predictores de la recuperación de la NBR para todos los tipos forestales, y explicaron del 2 al 6\% de la variación en la recuperación de la NBR post fuego. Las anomalías climáticas post fuego fueron también importantes predictores de la recuperación de la NBR y explicaron de un 30 a un $41 \%$ adicional en la variación de recuperación post fuego de la NBR.

Conclusiones: El análisis de las series temporales de Landsat resultó un método útil para describir y analizar la recuperación de la vegetación post fuego a través de eventos de fuego de diferente severidad. Demostramos que existe una relación entre la recuperación de la vegetación post fuego y el clima en bosques templados del oeste de Norte América. Nuestros métodos pueden ser aplicados a otros paisajes quemados para los cuales sean necesarias mediciones explícitas de la recuperación de la vegetación.

\section{Abbreviations}

\%RMSE: Percent root mean square error \%VE: percent variance explained

CBI: Composite Burn Index

CURV: McNab's curvature

DIST: Distance to unburn

dNBR: differenced Normalized Burn Ratio

ELEV: Elevation above sea level

ETM+: Landsat Enhanced Thematic Mapper Plus

EVI: Enhanced Vegetation Index

GSP: Post-fire anomaly of growing season precipitation

LandTrendr Landsat-based detection of Trends in Disturbance and Recovery

MAT: Post-fire anomaly of mean annual temperature

MIR: Model Improvement Ratio

MMAX: Post-fire anomaly of mean maximum temperature in warmest month

MMIN: Post-fire anomaly of mean minimum temperature in coldest month

MTBS: Monitoring Trends in Burn Severity

NBR: Normalized Burn Ratio
NDSWIR: Normalized Difference Shortwave Infrared Index

NDVI: Normalized Difference Vegetation Index

OLI: Landsat Operational Land Imager

RF: Random Forest

SLOPE: Slope

SR: Simple Ratio

SRTM: Shuttle Radar Topographic Mission

TM: Landsat Thematic Mapper

TRASP: Transformed aspect

VRI: Vegetation Recovery Index

WINP: Post-fire anomaly of winter precipitation

\section{Background}

Wildfires have burned millions of hectares in western North America in recent decades (Littell et al. 2009, Yang et al. 2015, White et al. 2017). Increased wildfire activity is expected to continue under warmer and drier conditions (Westerling et al. 2006; Abatzoglou 2016), making ecosystem resilience and post-fire vegetation recovery of concern to researchers and land managers (Allen and Breshears 2015). Burn severity, the degree to which fire has affected 
vegetation and soil (Keeley 2009), can have a large influence on post-fire vegetation recovery (Chappell 1996; Turner and Romme 1999; Crotteau and Varner III 2013; Meng et al. 2015; Liu 2016; Yang et al. 2017; Meng et al. 2018). Other factors that can be important to post-fire vegetation recovery include vegetation type (Yang et al. 2017; Díaz-Delgado et al. 2002; Epting 2005), climate (Chappell 1996; Meng et al. 2015; Liu 2016), topography (Díaz-Delgado et al. 2002; Wittenberg et al. 2007; Sever and Leach 2012; Meng et al. 2015; Liu 2016), and distance to unburned patches and seed sources (Donato et al. 2009; Harvey and Donato 2016; Kemp and Higuera 2016). Long-term measurements of post-fire vegetation recovery for differing forest types and burn severities can provide useful information to researchers and land managers who seek to identify areas that could benefit from post-fire management.

Burn severity has traditionally been estimated on the ground based on post-fire tree crown status. Recently, the Composite Burn Index (CBI) has been widely used to estimate ground burn severity for relation to satellite measurements (Key 2006). Good correlation has been found between ground estimates of burn severity and the differenced Normalized Burn Ratio (dNBR; van Wagtendonk et al. 2004, Key 2006, Hudak et al. 2007, Keeley 2009) NBR is defined as:

$$
N B R=\frac{N I R-S W I R}{N I R+S W I R}
$$

where NIR and SWIR are near and shortwave infrared Landsat bands, respectively, which are sensitive to healthy vegetation and burned surfaces (White et al. 1996). NIR and SWIR bands correspond to Landsat Thematic Mapper (TM) and Enhanced Thematic Mapper Plus (ETM+) bands 4 and 7 , respectively, and Landsat Operational Land Imager (OLI) bands 5 and 7, respectively. The dNBR is defined as the difference of pre-fire NBR and post-fire NBR:

$$
d N B R=\left(\left(N B R_{\text {prefire }}-N B R_{\text {postfire }}\right) \times 1000\right)
$$

The Monitoring Trends in Burn Severity (MTBS) program aims to map burn severity using dNBR for fires $>404$ ha (>1000 acres) in size (western United States) from 1984 to present (Eidenshink et al. 2007). Maps of dNBR classified into low-, moderate-, and high-severity classes are commonly used to assess and describe burn severity and associated ecological impacts. Although classification into low-, moderate-, and high-severity classes under the MTBS program can be somewhat subjective (Eidenshink et al. 2007), generally, low-severity burn corresponds to damage to and consumption of ground herbaceous vegetation and some understory shrubs; moderate-severity burn indicates total damage to and consumption of understory vegetation with some canopy tree mortality; and high-severity burn indicates high or complete canopy tree mortality (Keeley 2009).

Collectively, the Landsat TM, ETM+, and OLI satellites have acquired $30 \mathrm{~m}$ resolution imagery of Earth at least every 16 days since 1984 . Methodologies such as the Landsat-based detection of Trends in Disturbance and Recovery (LandTrendr) algorithms that perform time series analysis of this rich image archive have become popular for vegetation trend analyses (Huang et al. 2010, Kennedy and Yang 2010; Verbesselt et al. 2010; Banskota et al. 2014). Numerous studies have described post-fire vegetation recovery with multispectral time series analysis in Mediterranean ecosystems (Viedma et al. 1997; Díaz-Delgado 2001; Díaz-Delgado et al. 2002; Riaño et al. 2002; Díaz-Delgado and Lloret 2003; Malak 2006; Hope and Tague 2007; Wittenberg et al. 2007; Röder et al. 2008; Minchella et al. 2009; Gouveia and DaCamara 2010; Solans Vila 2010; Vicente-Serrano and Pérez-Cabello 2011; Veraverbeke et al. 2012; Fernandez-Manso and Quintano 2016; Lanorte et al. 2014; Meng et al. 2014; Petropoulos et al. 2014; Yang et al. 2017) and boreal ecosystems (Hicke et al. 2003; Epting 2005; Goetz and Fiske 2006; Cuevas-González et al. 2009; Jin et al. 2012; Frazier and Coops 2015; Bartels et al. 2016; Liu 2016; Pickell et al. 2016; White et al. 2017; Yang et al. 2017; Frazier et al. 2018); other forest types have been less studied (Idris and Kuraji 2005; Lhermitte et al. 2011; Sever and Leach 2012; Chen et al. 2014; Chompuchan 2017; Yang et al. 2017; Hislop et al. 2018), with only a few studies conducted in ponderosa pine and mixed conifer forests of western North America (White et al. 1996; van Leeuwen 2008; van Leeuwen et al. 2010; Chen et al. 2011; Meng et al. 2015). Among these studies, the Normalized Difference Vegetation Index (NDVI) has most frequently been applied to indicate vegetation greenness. However, recent studies have found NBR to be less prone to saturation than NDVI when characterizing post-fire vegetation recovery (Chen et al. 2011; Pickell et al. 2016; White et al. 2017; Hislop et al. 2018), possibly because NBR is more sensitive than NDVI to vegetation structure and soil background reflectance, which is inversely proportional to green vegetation cover (or non-photosynthetic vegetation [NPV] cover; Key 2006, Pickell et al. 2016). Therefore, we chose to calculate NBR to capture not just the initial impact of the fire, but also to monitor vegetation or greenness recovery. To our knowledge, only a few studies have investigated the relationship between post-fire satellite-derived vegetation recovery and climate (Meng et al. 2014; Meng et al. 2015; Liu 2016) and few or no previous studies have demonstrated the use of cloud-based computation with satellite data for investigating post-fire vegetation recovery. 


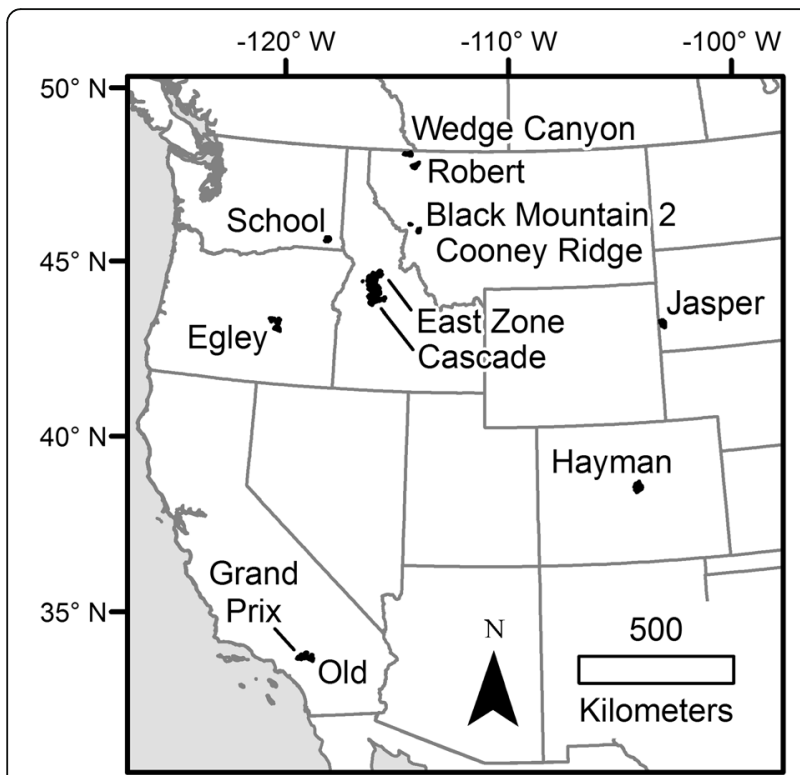

Fig. 1 Locations and names of the 12 wildfires in the western United States that were analyzed. Wildfires burned during the years 2000 to 2007

Here we analyzed post-fire vegetation recovery of 12 wildfires that occurred across the western United States during the years 2000 to 2007. Vegetation greenness, our metric of vegetation recovery, was inferred from LandTrendr-derived trajectories of NBR, which were generated in Google Earth Engine (Gorelick et al. 2017; Kennedy et al. 2018). Nonparametric random forest (RF) modeling was used to describe relationships between vegetation greenness and burn severity, climate, and topography. We sought to answer several fundamental questions: 1) How do rates of NBR recovery vary over time? 2) How quickly do fire patches appear to return to pre-fire spectral condition? 3) How do pre-fire condition, burn severity, and climate affect recovery?

\section{Methods}

\section{Study areas}

We focused on 12 named wildfire events in western North America that burned during the years 2000 to 2007 (Fig. 1, Table 1). Wildfires occurred in three different forest types: ponderosa pine, mixed conifer, and conifer-oak-chaparral. Mixed conifer forests consisted of grand fir (Abies grandis [Douglas ex D. Don] Lindl.), subalpine fir (Abies lasiocarpa [Hook.] Nutt.), western larch (Larix occidentalis Nutt.), Engelmann spruce (Picea engelmannii Parry ex Engelm.), lodgepole pine (Pinus contorta Douglas ex Loudon), ponderosa pine (Pinus ponderosa Lawson \& C. Lawson), Douglas-fir (Pseudotsuga menziesii [Mirb.] Franco), and quaking aspen (Populus tremuloides Michx.). The Old and Grand Prix fires (Table 1) occurred in forests dominated by California black oak (Quercus kelloggii Newberry), canyon live oak (Quercus chrysolepis Liebm.), and Coulter pine (Pinus coulteri D. Don). Mean annual temperature and precipitation varied between 2.8 and $14.9{ }^{\circ} \mathrm{C}$ and 328 and $662 \mathrm{~mm}$, respectively, across fire extents (1981 to 2010 climate normals; Table 1).

\section{Study area stratification}

Our study areas were part of a larger project (JFSP-14-1-02-27) that selected these wildfires for investigation and included field sampling of trees, understory vegetation, and fuels. To ensure representative sampling, pixels within each wildfire were stratified by burn severity, elevation, and transformed aspect (TRASP, Roberts 1989; Fig. 2). TRASP is defined as:

$$
\text { TRASP }=\frac{1-(\cos (\text { aspect }-30))}{2}
$$

where aspect is in degrees. TRASP ranges from 0 to 1 , with values of 0 corresponding to cooler, wetter northnortheastern aspects, and values of 1 corresponding to hotter, dryer south-southwestern aspects. To create the strata grid for each fire, a digital elevation model (DEM)

Table 1 Study area wildfires and characteristics

\begin{tabular}{|c|c|c|c|c|c|}
\hline Fire event & State & Fire year & Forest type & $\begin{array}{l}\text { Mean annual } \\
\text { temperature }\left({ }^{\circ} \mathrm{C}\right)\end{array}$ & $\begin{array}{l}\text { Mean annual } \\
\text { precipitation }(\mathrm{mm})\end{array}$ \\
\hline Egley & Oregon & 2007 & Ponderosa pine & 5.8 & 328 \\
\hline Hayman & Colorado & 2002 & Ponderosa pine & 5.0 & 435 \\
\hline Jasper & South Dakota & 2000 & Ponderosa pine & 5.5 & 548 \\
\hline School & Washington & 2005 & Mixed conifer & 6.6 & 554 \\
\hline Black Mountain 2 and Cooney Ridge & Montana & 2003 & Mixed conifer & 3.8 & 517 \\
\hline Cascade and East Zone & Idaho & 2007 & Mixed conifer & 2.0 & 555 \\
\hline Wedge Canyon and Robert & Montana & 2003 & Mixed conifer & 3.6 & 662 \\
\hline Old and Grand Prix & California & 2003 & Conifer-oak-chaparral & 15.0 & 425 \\
\hline
\end{tabular}



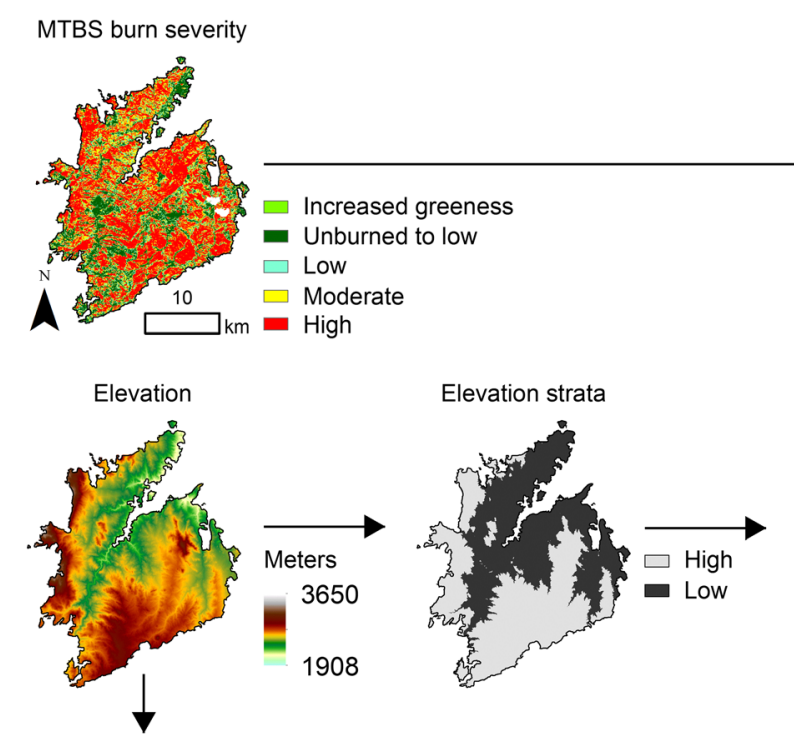

Stratification
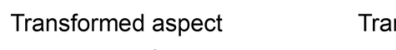

Transformed aspect strata
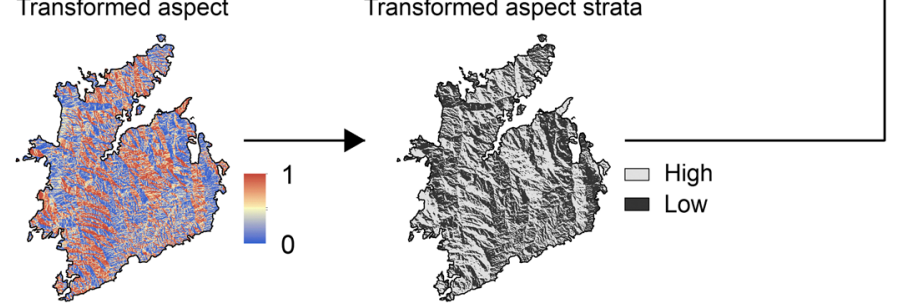

Fig. 2 Landscape stratification approach exemplified by the Hayman Fire, Colorado, USA, that burned in 2002. Elevation and transformed aspect grids were classified as low or high using medians. The MTBS burn severity class grid was then intersected with elevation and TRASP strata grids to create a stratification grid. For this analysis, we only considered areas burned at low, moderate, and high severity

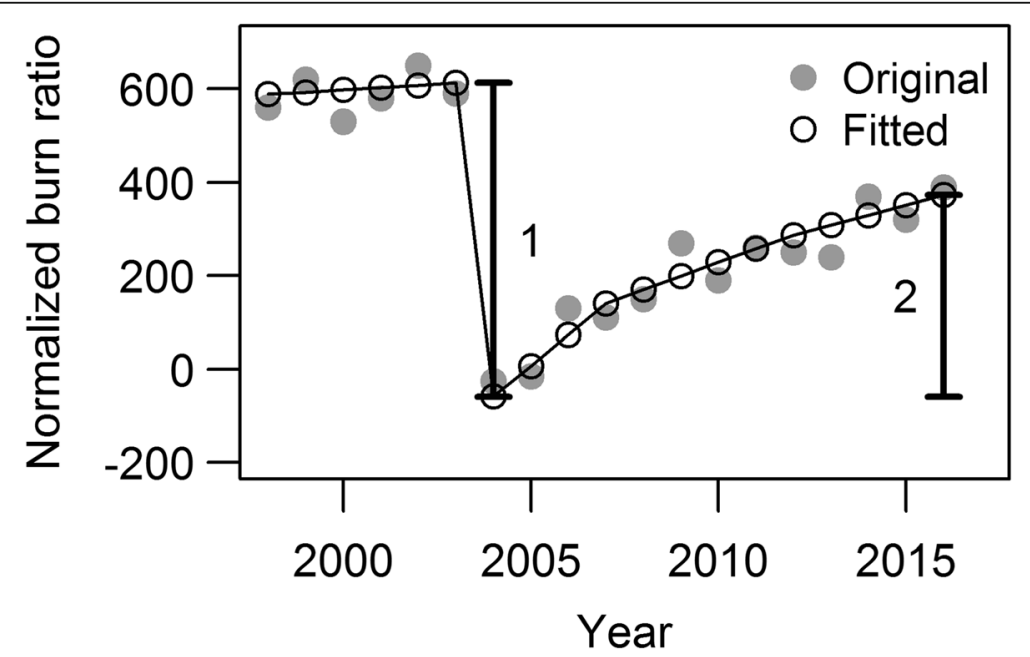

Fig. 3 Conceptual example of LandTrendr fitting normalized burn ratio (NBR) values to spectral-temporal segments for a pixel burned at high severity in the Cooney Ridge Fire in 2003. Original NBR values for a pixel time series are displayed as solid gray circles, and the corresponding fitted result from LandTrendr are open black circles. LandTrendr adjusts the original time series to fit to line segments between breakpoints in spectral trends. It eliminates noise and places each value in the context of spectral trajectories that combine to reveal the dominant, underlying spectral history of a pixel. Percent NBR recovery in 2016 was defined as distance 2 divided by distance 1 multiplied by 100 
grid and a TRASP grid were classified as low or high using the median, and the classified DEM, TRASP, and MTBS burn severity class grids were overlaid (Fig. 2). We grouped adjoining pixels of identical strata into patches, and used these patches as analysis units; no spatial patterning methods were used in patch creation. We chose to use patches rather than pixels as analysis units to reduce the millions of pixels covering our study areas to a more manageable size for analysis.

\section{Landsat time series data}

The NBR data used in this study were derived from the LandTrendr spectral-temporal segmentation algorithm. LandTrendr identifies breakpoints (referred to as vertices) in an image pixel time series between periods of relatively consistent spectral trajectory. From these breakpoints, a new time series is constructed, for which each annual observation is interpolated to fit on a line segment between vertices (Fig. 3). The result is an idealized, trajectory-based time series free from noise, for which each observation is placed in the context of a spectral-temporal trend. We chose this fitted data format over unaltered surface reflectance to reduce the influence of low-level time series variability resulting from variation in climate, atmosphere, phenology, sun angle, and other ephemeral effects on the calculation of post-fire percent NBR recovery, and to place the recovery in terms of a point along a trajectory.

Fitted NBR data were produced using the Google Earth Engine (Gorelick et al. 2017) implementation of LandTrendr (Kennedy et al. 2018). For each region, we assembled a collection of US Geological Survey surface reflectance images (Masek et al. 2006; Vermote et al. 2016) from 1984 to 2016, for dates 1 June through 30 September. The collection included images from TM,

Table 2 Climate and topographic variable names and descriptions

\begin{tabular}{ll}
\hline Variable & Description \\
\hline MAP & Post-fire anomaly of mean annual precipitation $(\mathrm{mm})$ \\
GSP & $\begin{array}{l}\text { Post-fire anomaly of growing season precipitation } \\
\text { (Apr to Sep; } \mathrm{mm})\end{array}$ \\
WINP & $\begin{array}{l}\text { Post-fire anomaly of winter precipitation } \\
\text { (Nov + Dec }+ \text { Jan }+ \text { Feb; } \mathrm{mm})\end{array}$ \\
MAT & Post-fire anomaly of mean annual temperature $\left({ }^{\circ} \mathrm{C}\right)$ \\
MMAX & Post-fire anomaly of mean maximum temperature in \\
MMIN & warmest month $\left({ }^{\circ} \mathrm{C}\right)$ \\
DIST & Post-fire anomaly of mean minimum temperature in \\
CURV & coldest month $\left({ }^{\circ} \mathrm{C}\right)$ \\
SLOPE & Distance to unburn (m) \\
TRASP & McNab's curvature (McNab 1989) \\
\hline
\end{tabular}

ETM+, and OLI sensors. Each image in the collection was masked to exclude clouds and cloud shadows using the CFMASK algorithm (Zhu and Wang 2015), which is provided with the surface reflectance product. Additionally, OLI image bands $2,3,4,5,6$, and 7 were transformed to the spectral properties of ETM+ bands 1, 2, 3, 4,5 , and 7 , respectively, using slopes and intercepts from reduced major axis regressions reported in Table 2 of Roy et al. (Roy et al. 2016).

Transforming OLI data to match ETM+ data permitted inter-sensor compositing to reduce multiple observations per year to a single annual spectral value, which is a requirement of the LandTrendr algorithm. To calculate composites, we used a medoid approach: for a given image pixel, the medoid is the value for a given band that is numerically closest to the median of all corresponding pixels among images considered. We selected the medoid compositing method to reduce variability that can be frequently introduced when using either maximum or minimum, and also to retain actual pixel values, as opposed to a summary statistic when using mean or median.

Medoid compositing was performed for each year in the collection and included images from any sensor contributing to the annual set of summer-season observations for the year being processed. The result was a single multi-band image, per year, free of clouds and cloud shadows, and represented median summer-season surface reflectance. From these annual medoid composites, NBR was calculated and provided as the time series input to the LandTrendr algorithm, whose parameters were set according to Table 2 of Kennedy et al. (Kennedy et al. 2012). The result from LandTrendr was an annual time series of NBR fitted to vertices of spectral-temporal segmentation.

We calculated zonal means of fitted NBR for the years 1984 to 2016 for each patch to be used for analysis. Percent NBR recovery, defined as the magnitude of NBR recovery divided by the magnitude of fire-induced decrease in NBR multiplied by 100 (Fig. 3), was calculated for each patch and year post fire. We tested whether percent NBR recovery varied significantly by burn severity at four, eight, and twelve years post fire for all three forest types with nonparametric Mann-Whitney tests. Percent NBR recovery nine years post fire was used as a response variable in RF models.

\section{Climate and topographic data}

We applied a spline model of climate developed for the western United States (e.g., Rehfeldt 2006; Rehfeldt et al. 2015) to produce the annual climatic predictor variables. The original model was applied to 30-year averages at $\sim 1 \mathrm{~km}$ resolution. These spatial and temporal scales could not capture finer scale variations in microclimate. To produce fine resolution annual climatic surfaces at 
$30 \mathrm{~m}$ resolution, we applied the model to annual climatic data for the years 1981 to 2010 using the digital elevation model from the Shuttle Radar Topographic Mission (SRTM). We used the ANUSPLIN program for thin plate spline interpolation of climatic variables (Hutchinson 2000). We then derived additional climatic indices and interactive variables from the original surface variables created by the model.

Climate variable indices were converted to post-fire climate anomaly grids because we were interested in how post-fire climate affected vegetation recovery, and so that across-fire climate comparisons could be made (Arnold et al. 2014; Meng et al. 2015; Liu 2016). Anomalies were calculated using the Z-statistic:

$$
Z=\frac{\mu_{\text {post }}-\mu_{\text {norm }}}{\sigma}
$$

where $\mu_{\text {post }}$ is the post-fire mean (one year post fire to $2010), \mu_{\text {norm }}$ is the climate normal (1984 to 2010) mean, and $\sigma$ is the climate normal standard deviation; the result was one mean anomaly grid for each climate variable. Post-fire means ended at 2010 because that was the last year of available climate data.

Topographic variable grids were derived from DEMs of each fire extent (Table 2). McNab's curvature was calculated using the spatialEco package in R (McNab 1989; $\mathrm{R}$ Core Team 2017; Evans 2017), and is a measure of slope shape, whether convex or concave. Curvature can affect soil moisture, erosion, and deposition, and thus vegetation growth. Distance to unburned was calculated as the shortest distance to the fire perimeter or an unburned patch. We calculated zonal means of climate anomalies and topographic variables for each patch to be used for RF analysis. Raster processing was performed in R using the raster package (Hijmans 2016; R Core Team 2017).

\section{Random forest analysis}

We explored the relationship between climate, topography, and post-fire NBR recovery by relating percent NBR recovery nine years post fire to post-fire climate anomaly and topographic variables (Table 2 ) via random forest (RF) modeling, implemented in R (Breiman 2001; Liaw 2002; R Core Team 2017). We chose to use a nonparametric modeling method because most variable distributions were non-normal and caused visibly nonrandom trends in residuals of initial linear models. RF modeling does not require variables to be normally distributed, can handle tens of thousands of cases, and provides variable importance scores.

We created RF models for each forest type using three different sets of explanatory variables to investigate how climate and topographic variables contributed to explaining variance in NBR recovery. Initial RF models included only pre-fire NBR (indicator of pre-fire vegetation cover) and dNBR (burn severity) as explanatory variables. Post-fire climate explanatory variables were then added and additional RF models were created, and finally topography variables were added as explanatory variables. We were computationally unable to create an RF model with all 263449 mixed conifer patches; therefore, we created 10 models using $10 \%$ samples of the mixed conifer patches, and averaged model results. RF models were evaluated with percent root mean square error (\%RMSE) and percent variance explained (\%VE) in percent NBR recovery, calculated as:

$$
\begin{aligned}
& \% R M S E=\frac{\sqrt{M S E}}{\overline{N B R_{\text {rec }}}} \times 100 \\
& \% V E=\frac{1-M S E}{\operatorname{var}\left(N B R_{\text {rec }}\right)} \times 100
\end{aligned}
$$

where $M S E$ is the mean square error, the sum of squared residuals divided by $n$, and $N B R_{\text {rec }}$ is percent NBR recovery. For RF models that included all explanatory variables, we calculated the model improvement ratio (MIR), a standardized measure of variable importance ranging between 0 and 1, for each variable (Murphy and Evans 2010). MIR measures were advantageous to raw importance scores because they were comparable between RF models. A MIR score of 1 indicated most important, 0 least important.

\section{Results}

\section{Patch statistics}

We examined a total of 435367 patches of variable size (Table 3). Patch size averaged 0.67 ha and ranged from 0.09 to 683.73 ha. Minimum and median patch sizes were one and two pixels, respectively. The Cascade and East Zone fires were the largest fires analyzed; the Black Mountain 2, Cooney Ridge, and School fires were the smallest fires analyzed.

\section{Vegetation recovery}

NBR recovery rates varied non-linearly by time since fire (Fig. 4, Additional file 1). The rate of NBR recovery was greatest several years following fire, after which it decreased. Patches that burned at high severity generally showed the greatest recovery, especially for the mixed conifer forest type. For ponderosa pine, patches that burned at moderate and high severity began to show less recovery than patches that burned at low severity, beginning 13 years post fire. Percent NBR recovery differed significantly by burn severity at four, eight, and twelve years post fire (considered representative of the recovery trends) for all three forest types (Mann-Whitney tests, $P$ $<0.001$ ); large sample sizes (Table 3) gave statistical tests 
Table 3 Patch number and size statistics for each fire event

\begin{tabular}{|c|c|c|c|c|c|c|}
\hline \multirow[b]{2}{*}{ Fire event } & \multirow[b]{2}{*}{ Total $(n)$} & \multicolumn{5}{|c|}{ Patch size (ha) } \\
\hline & & Minimum & Median & Mean & Maximum & SD \\
\hline Egley & 42674 & 0.09 & 0.18 & 0.53 & 597.33 & 4.28 \\
\hline Hayman & 62533 & 0.09 & 0.18 & 0.63 & 502.29 & 5.22 \\
\hline Jasper & 29092 & 0.09 & 0.18 & 0.78 & 229.77 & 3.31 \\
\hline School & 18214 & 0.09 & 0.18 & 0.58 & 88.29 & 2.15 \\
\hline Black Mountain 2 and Cooney Ridge & 6853 & 0.09 & 0.18 & 1.05 & 186.66 & 5.49 \\
\hline Cascade and East Zone & 203013 & 0.09 & 0.18 & 0.60 & 350.01 & 3.57 \\
\hline Wedge Canyon and Robert & 35369 & 0.09 & 0.18 & 1.00 & 566.73 & 6.53 \\
\hline Old and Grand Prix & 37619 & 0.09 & 0.18 & 0.93 & 683.73 & 6.74 \\
\hline
\end{tabular}

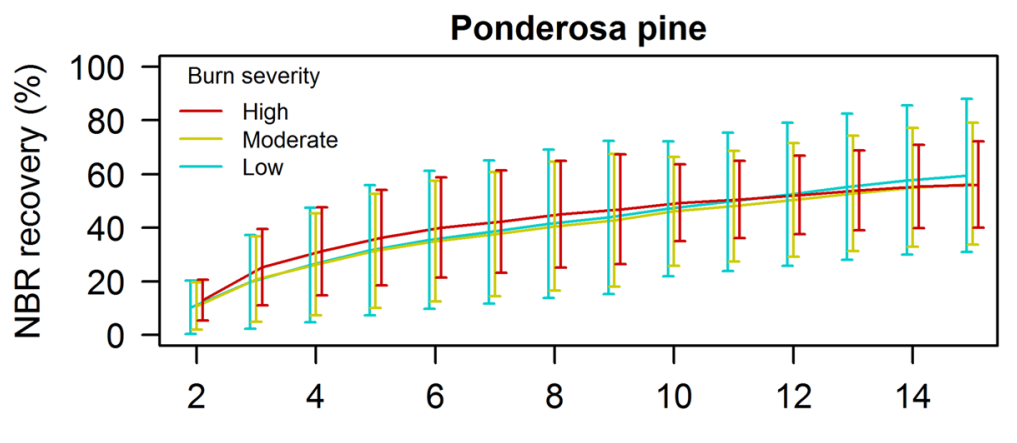

Mixed conifer

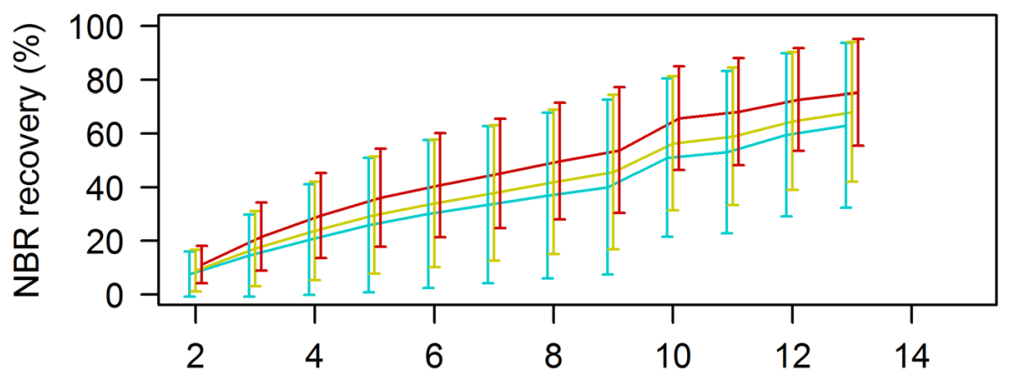

Conifer-oak-chaparral

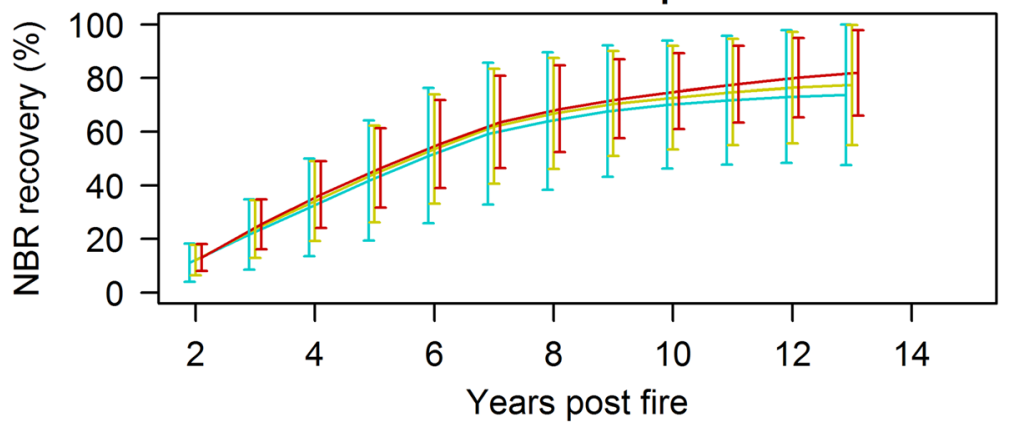

Fig. 4 Time series of percent recovery of mean percent Normalized Burn Ratio (NBR) for 12 wildfires in western North America that burned during the years 2000 to 2007. Bars show \pm 1 standard deviation. NBR recovery rates varied by severity, time since fire, and forest type 
Table 4 Average percent NBR recovery of patches by forest type and time since fire

\begin{tabular}{lccc}
\hline Forest type & \multicolumn{3}{l}{ Average NBR recovery (\%) } \\
\cline { 2 - 4 } & $5 \mathrm{yr}$ & $10 \mathrm{yr}$ & $13 \mathrm{yr}$ \\
\hline Ponderosa pine & 32 & 47 & 54 \\
Mixed conifer & 30 & 56 & 68 \\
Conifer-oak-chaparral & 44 & 72 & 77 \\
\hline
\end{tabular}

considerable power so that even small differences were significant (Fig. 4).

The rate of NBR recovery was smallest in the ponderosa pine forest type, intermediate in the mixed conifer forest type, and greatest in the conifer-oak-chaparral forest type (Fig. 4, Table 4). Recovery patterns for each fire event reflected this pattern, although individual fires showed some unique patterns as well (Additional file 1).

Most patches had not completely recovered to pre-fire NBR levels 9 to16 years after fire (Fig. 5). Among fires, 6 to 28,4 to 26 , and 1 to $22 \%$ of low-, moderate-, and high-severity patches, respectively, had recovered to pre-fire NBR levels. Greater percentages of patches that burned 13 to 16 years previously had recovered than patches that burned 9 to 11 years previously, with the exception of the Jasper and Hayman fires, which showed percent recovery values similar to the more recent fires.

\section{Post-fire climate anomalies}

Precipitation decreased post fire and temperatures generally remained the same or increased post fire, relative

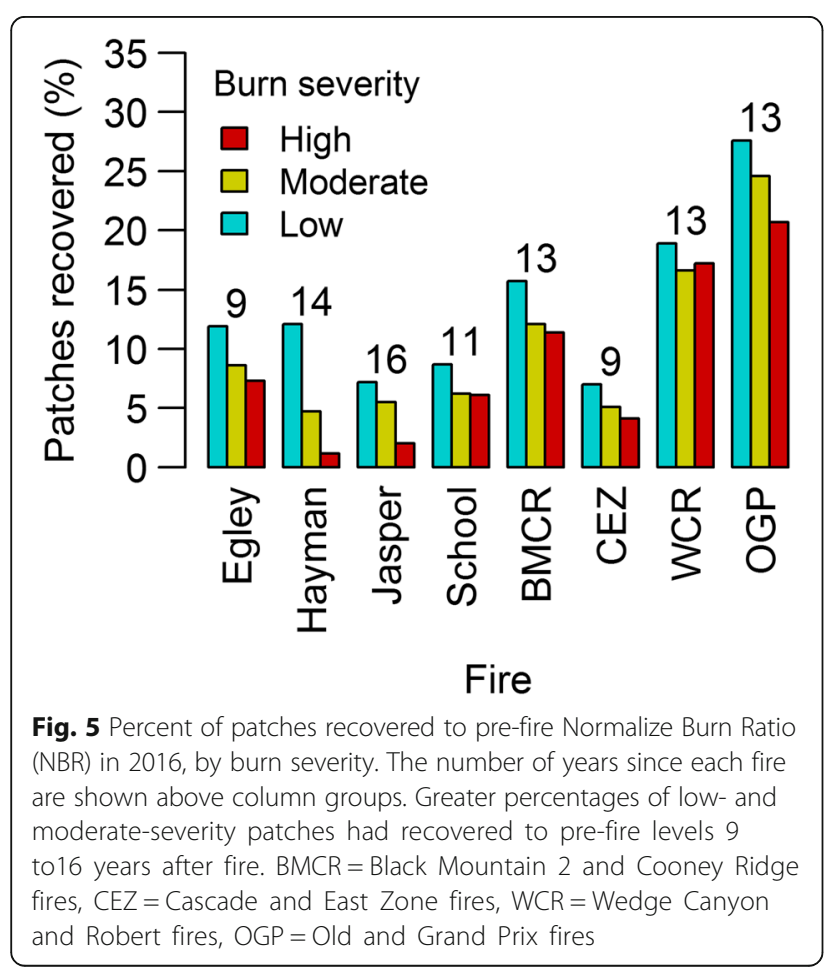

to climate normals, although exceptions existed (Fig. 6). Growing season precipitation decreased more than winter precipitation in most fire extents; post-fire precipitation decreases were greatest for the Cascade and East Zone fires. Mean annual temperatures decreased in the Cascade, East Zone, Wedge Canyon, and Robert fire extents; increased slightly in the School, Egley, Black Mountain 2, Cooney Ridge, and Jasper fire extents; and increased greatly in the Old, Grand Prix, and Hayman fire extents. Mean maximum temperatures in the warmest month were higher than long-term means in all fire extents except Cascade and East Zone, for which they stayed the same. Mean minimum temperatures in the coldest month decreased in the Egley, Cascade, East Zone, and Jasper fire extents; and increased in the School, Old, Grand Prix, Wedge Canyon, Robert, Black Mountain 2, Cooney Ridge, and Hayman fire extents.

\section{Random forest analysis}

RF models that included only pre-fire NBR and dNBR as explanatory variables explained 2 to $6 \%$ of the variation in NBR recovery nine years post fire (Table 5). Pre-fire NBR was important in predicting recovery across forest types (Table 6). Burn severity was less important in predicting recovery nine years post fire, especially for the ponderosa pine forest type. Post-fire climate explained an additional 30 to $41 \%$ of the variation in post-fire NBR recovery, and climate variables were important or very important predictors of recovery (Tables 5 and 6). Topographic variables were the least important predictors, and only explained an additional 2 to $6 \%$ of the variation in post-fire NBR recovery.

\section{Discussion}

We described post-fire vegetation recovery using NBR time series, and related post-fire climate and topographic variables to NBR recovery for 12 fires that occurred in temperate ecosystems of western North America. We documented average NBR recovery levels of 54 to $77 \%$ 13 years post fire, and that, in addition to pre-fire NBR and burn severity, post-fire climate was an important determinant of the degree that vegetation greenness had recovered post fire.

We found that most patches were still recovering to pre-fire NBR levels 9 to 16 years post fire. Longer time series of areas that burned earlier in the Landsat TM satellite record (beginning in 1984) would document more complete recovery to pre-fire NBR levels. Field observations of percent vegetation cover taken across our study areas 9 to 15 years post-fire confirmed that herbaceous and shrub species growth were responsible for the observed increase in NBR. Others who have also described vegetation recovery with satellite indices have generally reported faster or similar recovery rates for various 


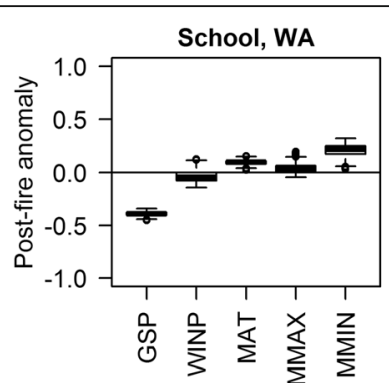

Egley, OR

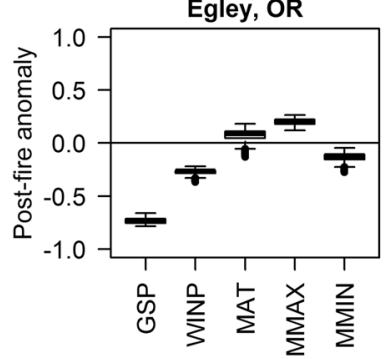

CEZ, ID

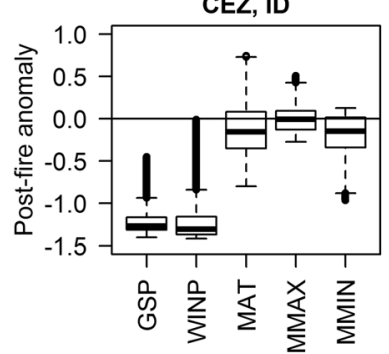

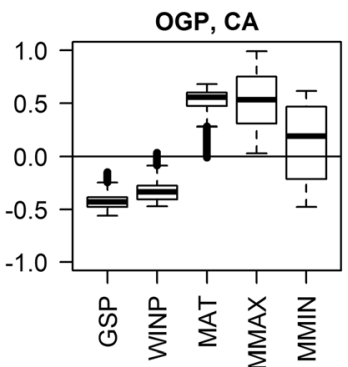

WCR, MT

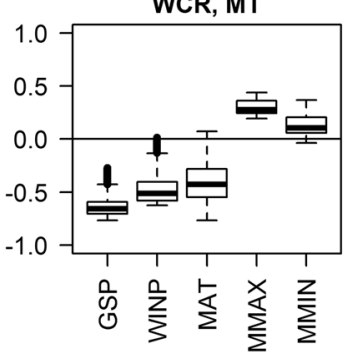

BMCR, MT

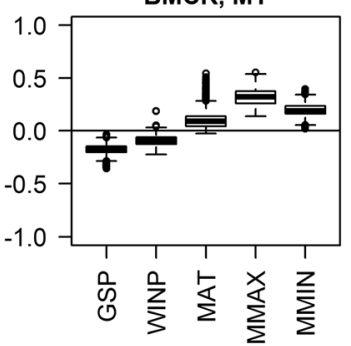

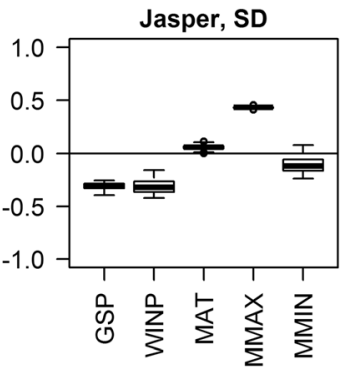

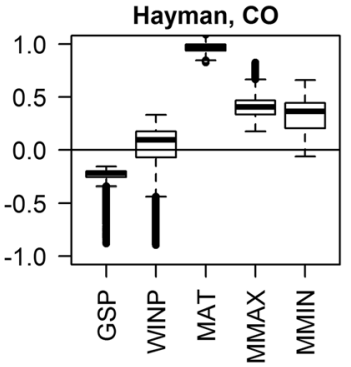

Fig. 6 Distributions of post-fire climate anomalies relative to climate normals (1984 to 2010). GSP = growing season precipitation, WINP= winter precipitation, $\mathrm{MAT}=$ mean annual temperature, $\mathrm{MMAX}=$ mean maximum temperature in warmest month, $\mathrm{MMIN}=$ mean minimum temperature in coldest month. Precipitation, especially growing season precipitation, decreased post fire for most areas. Temperature remained the same or increased for most areas. BMCR = Black Mountain 2 and Cooney Ridge fires, CEZ = Cascade and East Zone fires, WCR = Wedge Canyon and Robert fires, $\mathrm{OGP}=$ Old and Grand Prix fires. WA = Washington, $\mathrm{CA}=$ California, $\mathrm{SD}=$ South Dakota, $\mathrm{OR}=$ Oregon, $\mathrm{MT}=\mathrm{Montana}, \mathrm{CO}=\mathrm{Colorado}, \mathrm{ID}=\mathrm{Idaho}$

vegetation types (Table 7). Like Epting and Verbyla (Epting 2005), Jin et al. (Jin et al. 2012), and Meng et al. (Meng et al. 2018), we found that areas burned at higher severities recovered at faster rates than areas burned at lower severities, even after normalization by burn severity (Fig. 3), possibly because these are fire-adapted forest types in which fire creates favorable conditions for vegetation germination and regeneration (Zasada et al. 1983; Agee 1993; Meng et al. 2018).
Post-fire climate explained substantial variation in post-fire vegetation recovery. Although this finding is not surprising, as temperate forests of western North America are limited by summer precipitation and cold temperatures (Churkina 1998; Nemani et al. 2003), to our knowledge, few studies have documented the importance of climate to post-fire vegetation recovery. Meng et al. (2015) found that post-fire wet season precipitation and January minimum temperature helped

Table 5 Percent variance explained and percent root mean square error (\%RMSE) of random forest (RF) models predicting percent recovery of the Normalized Burn Ratio (NBR) nine years post fire from NBR variables alone; NBR and post-fire climate variables; and NBR, post-fire climate, and topographic variables

\begin{tabular}{lccr}
\hline & \multicolumn{2}{l}{ Percent variance explained (\%RMSE) } & Conifer-oak-chaparral \\
\cline { 2 - 4 } Explanatory variables & Ponderosa pine & Mixed conifer & $2(36)$ \\
\hline Pre-fire NBR, dNBR & $6(57)$ & $6(64)$ & $32(29)$ \\
Pre-fire NBR, dNBR, post-fire climate & $47(43)$ & $38(51)$ & $38(29)$ \\
Pre-fire NBR, dNBR, post-fire climate, topographic & $50(41)$ & $40(51)$ & 38 \\
\hline
\end{tabular}


Table 6 Model improvement ratio (MIR) scores of explanatory variables in random forest (RF) models predicting percent recovery of the Normalized Burn Ratio (NBR) nine years post fire. Variable importance scores range between 0 and 1, with 1 indicating most important and 0 indicating least important. $d N B R=$ diffrenced Normalzed Burn Ratio. See Table 2 for definitions of variables

\begin{tabular}{lccc}
\hline Variable & \multicolumn{3}{l}{ Model improvement ratio scores } \\
\cline { 2 - 4 } & Ponderosa pine & Mixed conifer & Conifer-oak-chaparral \\
\hline Pre-fire NBR & 0.9 & 1.0 & 1.0 \\
dNBR & 0.3 & 0.5 & 0.6 \\
MAP & 0.9 & 0.8 & 0.7 \\
GSP & 0.7 & 0.7 & 0.6 \\
WINP & 0.8 & 0.8 & 0.8 \\
MAT & 1.0 & 0.6 & 0.7 \\
MMAX & 0.7 & 0.9 & 0.8 \\
MMIN & 0.8 & 0.7 & 0.8 \\
DIST & 0.1 & 0.1 & 0.3 \\
CURV & 0.1 & 0.2 & 0.2 \\
SLOPE & 0.2 & 0.2 & 0.4 \\
TRASP & 0.1 & 0.1 & 0.2 \\
\hline
\end{tabular}

explain variation in NDVI five years post fire in mixed conifer and red fir forests in the Sierra Nevada Mountains of California, USA. They suggested that January minimum temperature might be a proxy for drought effects or indicate solar radiation and temperature limitations on vegetation growth in their forest types. Liu (2016) reported that post-fire summer precipitation was important to vegetation recovery five years post fire in boreal larch (Larix gmelinii [Rupr.] Rupr.) forests in China. Additional studies that use modeling approaches different from ours, like those of Meng et al. (2015) and Liu (2016), could describe relationships between burn severity, post-fire climate, topography, and post-fire vegetation recovery more specifically for the temperate coniferous forests that we studied. Although we found topographic variables to be unimportant predictors of NBR recovery, variations in fine-scale climate data were caused by local variability in elevation, so climate and elevation were convolved, and topography was possibly more influential than our modeling results suggested.

Post-fire NBR recovery was fastest and greatest for the conifer-oak-chaparral forest type (Fig. 4); this is possibly because vegetation was less limited by cold temperatures relative to other forest types (Table 1). Mixed conifer forests showed a greater post-fire recovery rate than ponderosa pine forests (Fig. 4), possibly because of richer species diversity and because mixed conifer forests tend to receive more precipitation (Table 1); the relative rapid recovery of the Wedge Canyon and Robert fires, which averaged the most precipitation of all our study areas, also supports this idea (Additional file 1: Figure S1). Likewise, the slower recovery of the Cascade and East Zone fires relative to the other mixed conifer

Table 7 Average recovery times reported in previous studies that used satellite indices to describe post-fire vegetation recovery. $\mathrm{NDVI}=$ Normalized Difference Vegetation Index, NDSWIR = Normalized Difference Shortwave Infrared Index, EVI = Enhanced Vegetation Index, VRI = Vegetation Recovery Index, BRR = Burn Recovery Ratio, NPP = Net Primary Productivity (derived from NDVI and Simple Ratio [SR])

\begin{tabular}{|c|c|c|c|c|c|}
\hline Authors & Year & Vegetation type & Location & Index & Reported mean recovery time (yr) \\
\hline Viedma et al. & 1997 & Mediterranean & Spain & $\mathrm{NDVI}$ & 1 to 18 \\
\hline Hicke et al. & 2003 & Boreal & Canada & NPP & 9 \\
\hline Epting and Verbyla & 2005 & Boreal & Alaska, USA & NDVI, NBR & 8 to 14 \\
\hline Idris et al. & 2005 & Tropical, temperate forest & Borneo, China & $\mathrm{NDVI}$ & 1 to 4 \\
\hline Hope et al. & 2007 & Chaparral & California, USA & $\mathrm{NDVI}$ & 10 \\
\hline Wittenberg et al. & 2007 & Mediterranean & Israel & $\mathrm{EVl}$ & 3 \\
\hline Cuevas-González et al. & 2009 & Boreal & Siberia, Russia & NDVI, NDSWIR & 13 \\
\hline Gouveia et al. & 2010 & Pinus L., Eucalyptus L'Hér & Portugal & $\mathrm{NDVI}$ & 3 to 5 \\
\hline Jin et al. & 2012 & Boreal & Canada & $\mathrm{EVl}$ & 5 to 8 \\
\hline Fernandez-Manso et al. & 2016 & Pinus & Spain & VRI & 7 to 20 \\
\hline Pickell et al. & 2016 & Boreal & Canada & NBR & 5.6 \\
\hline Chompuchan and Lin & 2017 & Pinus & Taiwan & BRR & 20 to 30 \\
\hline White et al. & 2017 & Boreal & Canada & NBR & Variable \\
\hline Yang et al. & 2017 & Boreal & Norht America & NDVI & $>10$ \\
\hline Frazier et al. & 2018 & Boreal & Canada & NBR & Variable \\
\hline Hislop et al. & 2018 & Sclerophyll & SE Australia & NBR & 8 to 10 \\
\hline
\end{tabular}


areas might have been due to greater relative decreases in post-fire precipitation (Additional file 1, Fig. 6).

We used recovery of NBR, a satellite index, as an indicator of vegetation recovery. Although satellite observations contain valuable information about vegetation conditions, they are simply measurements of reflected light and are therefore limited in their interpretability. NBR is an indication of the ratio of vegetation to soil cover, but tells us little about vegetation type and structure. Relating ground and satellite observations can increase interpretability of satellite observations (Hudak et al. 2007), as well as provide a means for applying spatially limited ground observations across landscapes. We chose to limit this analysis to NBR observations because we wished to describe landscape-wide vegetation recovery in general. Future studies that predict ground-measured vegetation characteristics from time series of multispectral imagery could describe post-fire recovery trajectories of more specific vegetation characteristics.

\section{Conclusions}

Landsat time series analysis can provide landscape-wide information on post-fire vegetation recovery. Our analysis revealed that complete post-fire recovery of NBR in the temperate forest ecosystems of western North America takes longer than 9 to 16 years for most areas. We found burn severity, pre-fire NBR, and post-fire climate to be important to vegetation recovery for the fires that we studied. Methods similar to ours could be applied to other burned areas for which landscape-wide information on post-disturbance vegetation recovery is needed, and could be used to inform management decisions; for instance, individual patches showing little or no recovery could be identified for post-fire management. Our finding that post-fire climate influences vegetation recovery suggests that climate change will affect post-fire vegetation recovery in western North America.

\section{Additional file}

Additional file 1: Time series of percent recovery of mean percent Normalized Burn Ratio (NBR) by burn severity for each fire. Bars show \pm 1 standard deviation. NBR recovery rates varied by fire, severity, time since fire, and forest type. Forest type, year of fire, mean average temperature $\left({ }^{\circ} \mathrm{C}\right)$, and mean annual precipitation $(\mathrm{mm})$ are given in the upper left-hand corner of each panel. (TIF 457 kb)

\section{Acknowledgements}

The authors thank three anonymous reviewers for their time and helpful reviews.

\section{Funding}

Research was funded by the Joint Fire Science Program (JFSP-14-1-02-27).

\section{Availability of data and materials}

The datasets used and analyzed during the current study are available from the corresponding author on reasonable request.

\section{Authors' contributions}

$\mathrm{BB}$ and $\mathrm{AH}$ conceived and designed the analysis; $\mathrm{BB}$ performed the analysis; RK and JB provided Landsat time series data. AHK provided climate data. BB, AH, RK, JB, and AHK wrote the manuscript. All authors read and approved the final manuscript.

Ethics approval and consent to participate

Not applicable.

\section{Consent for publication}

Not applicable.

\section{Competing interests}

The authors declare that they have no competing interests.

\section{Publisher's Note}

Springer Nature remains neutral with regard to jurisdictional claims in published maps and institutional affiliations.

\section{Author details}

'USDA Forest Service, Rocky Mountain Research Station, 1221 S. Main Street, Moscow, Idaho 83843, USA. ${ }^{2}$ Oregon State University, College of Earth, Ocean, and Atmospheric Sciences, 104 CEOAS Administration Building, 101 SW 26th Street, Corvallis, Oregon 97331, USA. ${ }^{3}$ Natural Resource Ecology Laboratory, Colorado State University, NESB Building, 1499 Campus Delivery, A215, Fort Collins, Colorado 80523, USA.

Received: 1 June 2018 Accepted: 18 November 2018

Published online: 10 April 2019

\section{References}

Abatzoglou, J.T., and A.P. Williams. 2016. Impact of anthropogenic climate change on wildfire across western US forests. PNAS 113: 11770-11775. https://doi.org/10.1073/pnas.1607171113.

Agee, J.K. 1993. Fire ecology of Pacific Northwest forests. Washington, D.C: Island Press.

Allen, C.D., D.D. Breshears, and N.G. McDowell. 2015. On underestimation of global vulnerability to tree mortality and forest die-off from hotter drought in the Anthropocene. Ecosphere 6: 1-55. https://doi.org/10.1890/ ES15-00203.1.

Arnold, J.D., S.C. Brewer, and P.E. Dennison. 2014. Modeling climate-fire connections within the Great Basin and Upper Colorado River Basin, western United States. Fire Ecology 10: 64-75. https://doi.org/10.4996/fireecology. 1002064.

Banskota, A., N. Kayastha, M.J. Falkowski, M.A. Wulder, R.E. Froese, and J.C. White. 2014. Forest monitoring using Landsat time series data: a review. Canadian Journal of Remote Sensing 40: 3623-3684. https://doi.org/10.1080/07038992. 2014.987376

Bartels, S.F., H.Y.H. Chen, M.A. Wulder, and J.C. White. 2016. Trends in postdisturbance recovery rates of Canada's forests following wildfire and harvest. Forest Ecology and Management 361: 194-207. https://doi.org/10.1016/j. foreco.2015.11.015.

Breiman, L. 2001. Random forests. Machine Learning 45: 5-32. https://doi.org/10. 1023/A:1010933404324

Chappell, C.B., and J.K. Agee. 1996. Fire severity and tree seedling establishment in Abies magnifica forests, southern Cascades, Oregon. Ecological Applications 6: 628-640. https://doi.org/10.2307/2269397.

Chen, W., K. Moriya, T. Sakai, L. .Koyama, and C. Cao. 2014. Monitoring of post-fire forest recovery under different restoration modes based on time series Landsat data. European Journal of Remote Sensing 47: 153-168. https://doi. org/10.5721/EuJRS20144710.

Chen, X., J.E. Vogelmann, M. Rollins, D. Ohlen, C.H. Key, L. Yang, C. Huang, and H. Shi. 2011. Detecting post-fire burn severity and vegetation recovery using multitemporal remote sensing spectral indices and field-collected composite burn index data in a ponderosa pine forest. International Journal of Remote Sensing 32: 7905-7927. https://doi.org/10.1080/01431161.2010.524678.

Chompuchan, C., and C.Y. Lin. 2017. Assessment of forest recovery at Wu-Ling fire scars in Taiwan using multi-temporal Landsat imagery. Ecological Indicators 79: 196-206. https://doi.org/10.1016/j.ecolind.2017.04.038. 
Churkina, G., and S.W. Running. 1998. Contrasting climatic controls on the estimated productivity of global terrestrial biomes. Ecosystems 1: 206-215. https://doi.org/10.1007/s100219900016.

Crotteau, J.S., J.M. Varner III, and M.W. Ritchie. 2013. Post-fire regeneration across a fire severity gradient in the southern Cascades. Forest Ecology and Management 287: 103-112. https://doi.org/10.1016/j.foreco.2012.09.022.

Cuevas-González, M., F. Gerard, H. Balzter, and D. Riaño. 2009. Analysing forest recovery after wildfire disturbance in boreal Siberia using remotely sensed vegetation indices. Global Change Biology 15: 561-577. https://doi.org/10. 1111/j.1365-2486.2008.01784.x.

Díaz-Delgado, R., and X. Pons. 2001. Spatial patterns of forest fires in Catalonia (NE of Spain) along the period 1975-1995: analysis of vegetation recovery after fire. Forest Ecology and Management 147: 67-74. https://doi.org/10.1016/ S0378-1127(00)00434-5.

Díaz-Delgado, R., F. Lloret, and X. Pons. 2003. Influence of fire severity on plant regeneration by means of remote sensing imagery. International Journal of Remote Sensing 24: 1751-1763. https://doi.org/10.1080/01431160210144732.

Díaz-Delgado, R., F. Lloret, X. Pons, and J. Terradas. 2002. Satellite evidence of decreasing resilience in Mediterranean plant communities after recurrent wildfires. Ecology 83: 2293-2303.

Donato, D.C., J.B. Fontaine, J.L. Campbell, W.D. Robinson, J.B. Kauffman, and B.E. Law. 2009. Conifer regeneration in stand-replacement portions of a large mixed-severity wildfire in the Klamath-Siskiyou Mountains. Canadian Journal of Forest Research 39: 823-838. https://doi.org/10.1139/X09-016.

Eidenshink, J., B. Schwind, K. Brewer, Z. Zhu, B. Quayle, and S. Howard. 2007. A project for monitoring trends in burn severity. Fire Ecology 3: 3-21. https:// doi.org/10.4996/fireecology.0301003.

Epting, J., and J. Verbyla. 2005. Landscape-level interactions of prefire vegetation, burn severity, and postfire vegetation over a 16-year period in interior Alaska. Canadian Journal of Forest Research 35: 1367-1377. https://doi.org/10.1139/X05-060.

Evans, J.S. 2017. spatialEco. R package version 0.0.1-7. https://CRAN.R-project.org/ package $=$ spatialEco. Accessed January 2018

Fernandez-Manso, A., C. Quintano, and D.A. Roberts. 2016. Burn severity influence on post-fire vegetation cover resilience from Landsat MESMA fraction images time series in Mediterranean forest ecosystems. Remote Sensing of Environment 184: 112-123. https://doi.org/10.1016/j.rse.2016.06.015.

Frazier, R.J., N.C. .Coops, M.A. Wulder, T. Hermosilla, and J.C. White. 2018. Analyzing spatial and temporal variability in short-term rates of post-fire vegetation return from Landsat time series. Remote Sensing of Environment 205: 32-45. https://doi.org/10.1016/j.rse.2017.11.007.

Frazier, R.J., N.C. Coops, and M.A. Wulder. 2015. Boreal Shield forest disturbance and recovery trends using Landsat time series. Remote Sensing of Environment 170: 317-327. https://doi.org/10.1016/j.rse.2015.09.015.

Goetz, S.J., G.J. Fiske, and A.G. Bunn. 2006. Using satellite time-series data sets to analyze fire disturbance and forest recovery across Canada. Remote Sensing of Environment 101: 352-365. https://doi.org/10.1016/j.rse.2006.01.011.

Gorelick, N., M. Hancher, M. Dixon, S. Ilyushchenko, D. Thau, and R. Moore. 2017. Google Earth Engine: planetary-scale geospatial analysis for everyone. Remote Sensing of Environment 202: 18-27. https://doi.org/10.1016/j.rse.2017.06.031.

Gouveia, C., C.C. DaCamara, and R.M. Trigo. 2010. Post-fire vegetation recovery in Portugal based on spot/vegetation data. Natural Hazards and Earth System Sciences 10: 673-684. https://doi.org/10.5194/nhess-10-673-2010.

Harvey, B.J., D.C. Donato, and M.G. Turner. 2016. High and dry: post-fire tree seedling establishment in subalpine forests decreases with post-fire drought and large stand-replacing burn patches. Global Ecology and Biogeography 25: 655-669. https://doi.org/10.1111/geb.12443

Hicke, J.A., G.P. Asner, E.S. Kasischke, N.H.F. French, J.T. Randerson, GJ. Collatz, B.J. Stocks, C. J. Tucker, S.O. Los, and C.B. Field. 2003. Postfire response of North American boreal forest net primary productivity analyzed with satellite observations. Global Change Biology 9: 1145-1157. https://doi.org/10.1046/j.1365-2486.2003.00658x.

Hijmans, RJ. 2016. raster: geographic data analysis and modeling. $R$ package version 2: 5-8 https://CRAN.R-project.org/package=raster. Accessed January 2018.

Hislop, S., S. Jones, M. Soto-Berelov, A. Skidmore, A. .Haywood, and T.H. Nguyen. 2018. Using Landsat spectral indices in time-series to assess wildfire disturbance and recovery. Remote Sensing 10: 460. https://doi.org/10.3390/rs10030460.

Hope, A., C. Tague, and R. Clark. 2007. Characterizing post-fire vegetation recovery of California chaparral using TM/ETM+ time-series data. International Journal of Remote Sensing 28: 1339-1354. https://doi.org/10.1080/ 01431160600908924.

Huang, C., S.N. Goward, J.G. Masek, N. Thomas, Z. Zhu, and J.E. Vogelmann. 2010. An automated approach for reconstructing recent forest disturbance history using dense Landsat time series stacks. Remote Sensing of Environment 114 183-198. https://doi.org/10.1016/j.rse.2009.08.017.

Hudak, A.T., P. Morgan, M.J. Bobbitt, A.M.S. Smith, S.A. Lewis, L.B. Lentile, P.R. Robichaud, J.T. Clark, and R.A. McKinley. 2007. The relationship of multispectral satellite imagery to immediate fire effects. Fire Ecology 3: 64-90. https://doi.org/10.4996/fireecology.0301064.

Hutchinson, M.F. 2000. ANUSPLIN user guide version 4.1. Centre for Resource and Environmental Studies. Canberra: Australian National University.

Idris, M.H., K. Kuraji, and M. Suzuki. 2005. Evaluating vegetation recovery following large-scale forest fires in Borneo and northeastern China using multitemporal NOAAVAVHRR images. Journal of Forest Research 10: 101-111. https://doi.org/10.1007/s10310-004-0106-y.

Jin, Y., J.T. Randerson, S.J. Goetz, P.S.A. Beck, M.M. Loranty, and M.L. Goulden. 2012. The influence of burn severity on postfire vegetation recovery and albedo change during early succession in North American boreal forests. Journal of Geophysical Research 117: G01036. https://doi.org/10.1029/2011JG001886.

Keeley, J.E. 2009. Fire intensity, fire severity and burn severity: a brief review and suggested usage. International Journal of Wildland Fire 18: 116-126. https:// doi.org/10.1071/WF07049.

Kemp, K.B., P.E. Higuera, and P. Morgan. 2016. Fire legacies impact conifer regeneration across environmental gradients in the US northern Rockies. Landscape Ecology 31: 619. https://doi.org/10.1007/s10980-015-0268-3.

Kennedy, R.E., Z. Yang, W.B. Cohen, E. Pfaff, J. Braaten, and P. Nelson. 2012. Spatial and temporal patterns of forest disturbance and regrowth within the area of the Northwest Forest Plan. Remote Sensing of Environment 122: 117-133. https://doi.org/10.1016/j.rse.2011.09.024.

Kennedy, R.E., Z. Yang, N. Gorelick, J. Braaten, L. Cavalcante, W.B. Cohen, and S. Healey. 2018. Implementation of the LandTrendr algorithm on Google Earth Engine. Remote Sensing 10: 691. https://doi.org/10.3390/rs10050691.

Kennedy, R.E., Z.G. Yang, and W.B. Cohen. 2010. Detecting trends in forest disturbance and recovery using yearly Landsat time series: 1. LandTrendrtemporal segmentation algorithms. Remote Sensing of Environment 114: 2897-2910. https://doi.org/10.1016/j.rse.2010.07.008.

Key, C.H., and N.C. Benson. 2006. Landscape assessment: ground measure of severity, the Composite Burn Index; and remote sensing of severity, the Normalized Burn Ratio. Pages LA1-LA51. In FIREMON: fire effects monitoring and inventory system, ed. D.C. Lutes, R.E. Keane, J.F. Caratti, C.H. Key, N.C. Benson, S. Sutherland, and L.J. Gangi. Fort Collins: USDA Forest Service General Technical Report RMRS-GTR164-CD, Rocky Mountain Research Station.

Lanorte, A., R. Lasaponara, M. Lovallo, and L. Telesca. 2014. Fisher-Shannon information plane analysis of SPOTNEGETATION Normalized Difference Vegetation Index (NDVI) time series to characterize vegetation recovery after fire disturbance. International Journal of Applied Earth Observation and Geoinformation 26: 441-446. https://doi.org/10.1016/j.jag.2013.05.008.

Lhermitte, S., J. Verbesselt, W.W. Verstraeten, S. Veraverbeke, and P. Coppin. 2011. Assessing intra-annual vegetation regrowth after fire using the pixel based regeneration index. ISPRS Journal of Photogrammetry and Remote Sensing 66: 17-27. https://doi.org/10.1016/j.isprsjprs.2010.08.004

Liaw, A., and M. Wiener. 2002. Classification and regression by randomForest. $R$ News 2: 18-22 https://cran.r-project.org/doc/Rnews/Rnews_2002-3.pdf. Accessed Jan 2018.

Littell, J.S., D. McKenzie, D.L. Peterson, and A.L. Westerling. 2009. Climate and wildfire area burned in western US ecoprovinces, 1916-2003. Ecological Applications 19: 1003-1021. https://doi.org/10.1890/07-1183.1.

Liu, Z. 2016. Effects of climate and fire on short-term vegetation recovery in the boreal larch forests of northeastern China. Scientific Reports 6: 37572. https:// doi.org/10.1038/srep37572.

Malak, D.A., and J.G. Pausas. 2006. Fire regime and post-fire Normalized Difference Vegetation Index changes in the eastern Iberian peninsula (Mediterranean Basin). International Journal of Wildland Fire 15: 407-413. https://doi.org/10.1071/WF05052.

Masek, J.G., E.F. Vermote, N.E. Saleous, R. Wolfe, F.G. Hall, K.F. Huemmrich, F. Gao, J. Kutler, and T.-K. Lim. 2006. A Landsat surface reflectance dataset for North America, 1990-2000. IEEE Geoscience and Remote Sensing Letters 3: 68-72. https://doi.org/10.1109/LGRS.2005.857030.

McNab, H.W. 1989. Terrain shape index: quantifying effect of minor landforms on tree height. Forest Science 35: 91-104.

Meng, R., P.E. Dennison, C.M. D'Antonio, and M.A. Moritz. 2014. Remote Sensing Analysis of vegetation recovery following short-interval fires in southern California shrublands. PLOS ONE 9: e110637. https://doi.org/10.1371/journal. pone.0110637. 
Meng, R., P.E. Dennison, C. Huang, M.A. Moritz, and C. D'Antonio. 2015. Effects of fire severity and post-fire climate on short-term vegetation recovery of mixed-conifer and red fir forests in the Sierra Nevada mountains of California. Remote Sensing of Environment 171: 311-325. https://doi.org/10.1016/j.rse.2015.10.024.

Meng, R., J. Wu, F. Zhao, B.D. Cook, R.P. Hanavan, and S.P. Serbin. 2018. Measuring short-term post-fire forest recovery across a burn severity gradient in a mixed pine-oak forest using multi-sensor remote sensing techniques. Remote Sensing of Environment 210: 282-296. https://doi.org/10.1016/j.rse.2018.03.019.

Minchella, A., F. Del Frate, F. Capogna, S. Anselmi, and F. Manes. 2009. Use of multitemporal SAR data for monitoring vegetation recovery of Mediterranean burned areas. Remote Sensing of Environment 113: 588-597. https://doi.org/10.1016/j.rse.2008.11.004.

Murphy, M.A., J.S. Evans, and A.S. Storfer. 2010. Quantify Bufo boreas connectivity in Yellowstone National Park with landscape genetics. Ecology 91: 252-261. https://doi.org/10.1890/08-0879.1.

Nemani, R.R., C.D. Keeling, H. Hashimoto, W.M. Jolly, S.C. Piper, C.J. Tucker, R.B. Myneni, and S.W. Running. 2003. Climate-driven increases in global terrestrial net primary production from 1982 to 1999. Science 300: 1560-1563. https:// doi.org/10.1126/science.1082750

Petropoulos, G.P., H.M. Griffiths, and D.P. Kalivas. 2014. Quantifying spatial and temporal vegetation recovery dynamics following a wildfire event in a Mediterranean landscape using EO data and GIS. Applied Geography 50: 120 131. https://doi.org/10.1016/j.apgeog.2014.02.006.

Pickell, P.D., T. Hermosilla, R.J. Frazier, N.C. Coops, and M.A. Wulder. 2016. Forest recovery trends derived from Landsat time series for North American borea forests. International Journal of Remote Sensing 37: 138-149. https://doi.org/ 10.1080/2150704X.2015.1126375.

R Core Team. 2017. R: a language and environment for statistical computing. Vienna: R Foundation for Statistical Computing.

Rehfeldt, G.E. 2006. A spline model of climate for the western United States, USDA Forest Service General technical Report RMRS-GTR-165. Fort Collins: Rocky Mountain Research Station.

Rehfeldt, G.E., J.J. Worrall, S.B. Marchetti, and N.L. Crookston. 2015. Adapting forest management to climate change using bioclimate models with topographic drivers. Forestry 88: 528-539. https://doi.org/10.1093/forestry/cpv019.

Riaño, D., E. Chuvieco, S. Ustin, R. Zomer, P. Dennison, D. Roberts, and J. Salas. 2002. Assessment of vegetation regeneration after fire through multitemporal analysis of AVIRIS images in the Santa Monica Mountains. Remote Sensing of Environment 79: 60-71. https://doi.org/10.1016/S00344257(01)00239-5.

Roberts, D.W., and S.V. Cooper. 1989. Concepts and techniques of vegetation mapping. Pages 90-96. In compilers. Proceedings of a symposium-land classifications based on vegetation: applications for resource management. USDA Forest Service General Technical Report INT-257, ed. D.E. Ferguson, P. Morgan, and F.D. Johnson. Ogden: Intermountain Research Station.

Röder, A., J. Hill, B. Duguy, J.A. Alloza, and R. Vallejo. 2008. Using long time series of Landsat data to monitor fire events and post-fire dynamics and identify driving factors. A case study in the Ayora region (eastern Spain). Remote Sensing of Environment 112: 259-273. https://doi.org/10.1016/j.rse. 2007.05.001.

Roy, D.P., V. Kovalskyy, H.K. Zhang, E.F. Vermote, L. Yan, S.S. Kumar, and A. Egorov. 2016. Characterization of Landsat-7 to Landsat-8 reflective wavelength and normalized difference vegetation index continuity. Remote Sensing of Environment 185: 57-70. https://doi.org/10.1016/j.rse.2015.12.024.

Sever, L., J. Leach, and L. Bren. 2012. Remote sensing of post-fire vegetation recovery; a study using Landsat 5 TM imagery and NDVI in north-east Victoria. Journal of Spatial Science 57: 175-191. https://doi.org/10.1080/ 14498596.2012.733618.

Solans Vila, J.P., and P. Barbosa. 2010. Post-fire vegetation regrowth detection in the Deiva Marina region (Liguria-Italy) using Landsat TM and ETM+ data. Ecological Modelling 221: 75-84. https://doi.org/10.1016/j.ecolmodel.2009.03.011.

Turner, M.G., W.H. Romme, and R.H. Gardner. 1999. Pre-fire heterogeneity, fire severity, and early post-fire plant reestablishment in subalpine forests of Yellowstone National Park, Wyoming. International Journal of Wildland Fire 9: 21-36. https://doi.org/10.1071/WF99003.

van Leeuwen, W.J.D. 2008. Monitoring the effects of forest restoration treatments on post-fire vegetation recovery with MODIS multitemporal data. Sensors 8: 2017-2042. https://doi.org/10.3390/s8032017.

van Leeuwen, W.J.D., G.M. Casady, D.G. Neary, S. Bautista, J.A. Alloza, Y. Carmel, L. Wittenberg, D. Malkinson, and B.J. Orr. 2010. Monitoring post-wildfire vegetation response with remotely sensed time-series data in Spain, USA and Israel. International Journal of Wildland Fire 19: 75-93. https://doi.org/10. 1071/WF08078

van Wagtendonk, J.W., R.R. Root, and C.H. Key. 2004. Comparison of AVIRIS and Landsat ETM+ detection capabilities for burn severity. Remote Sensing of Environment 92: 397-408. https://doi.org/10.1016/j.rse.2003.12.015.

Veraverbeke, S., I. Gitas, T. Katagis, A. Polychronaki, B. Somers, and R. Goossens. 2012. Assessing post-fire vegetation recovery using red-near infrared vegetation indices: accounting for background and vegetation variability. ISPRS Journal of Photogrammetry and Remote Sensing 68: 28-39. https://doi. org/10.1016/j.isprsjprs.2011.12.007.

Verbesselt, J., R. Hyndman, G. Newnham, and D. Culvenor. 2010. Detecting trend and seasonal changes in satellite image time series. Remote Sensing of Environment 114: 106-115. https://doi.org/10.1016/j.rse.2009.08.014.

Vermote, E., C. Justice, M. Claverie, and B. Franch. 2016. Preliminary analysis of the performance of the Landsat 8/OLI land surface reflectance product. Remote Sensing of Environment 185: 46-56. https://doi.org/10. 1016/j.rse.2016.04.008.

Vicente-Serrano, S.M., F. Pérez-Cabello, and T. Lasanta. 2011. Pinus halepensis regeneration after a wildfire in a semiarid environment: assessment using multitemporal Landsat images. International Journal of Wildland Fire 20: 195208. https://doi.org/10.1071/WF08203.

Viedma, O., J. Meliá, D. Segarra, and J. García-Haro. 1997. modeling rates of ecosystem recovery after fires by using Landsat TM data. Remote Sensing of Environment 61: 383-398. https://doi.org/10.1016/S0034-4257(97)00048-5.

Westerling, A.L., H.G. Hidalgo, D.R. Cayan, and T.W. Swetnam. 2006. Warming and earlier spring increase western US forest wildfire activity. Science 313: 940943. https://doi.org/10.1126/science.1128834.

White, J.C., M.A. Wulder, T. Hermosilla, N.C. Coops, and G.W. Hobart. 2017. A nationwide annual characterization of 25 years of forest disturbance and recovery for Canada using Landsat time series. Remote Sensing of Environment 194: 303-321. https://doi.org/10.1016/j.rse.2017.03.035.

White, J.D., K.C. Ryan, C.C. Key, and S.W. Running. 1996. Remote sensing of forest fire severity and vegetation recovery. International Journal of Wildland Fire 6: 125-136. https://doi.org/10.1071/WF9960125.

Wittenberg, L., D. Malkinson, O. Beeri, A. Halutzy, and N. Tesler. 2007. Spatial and temporal patterns of vegetation recovery following sequences of forest fires in a Mediterranean landscape, Mt. Carmel Israel. Catena 71: 76-83. https:// doi.org/10.1016/j.catena.2006.10.007.

Yang, J., S. Pan, S. Dangal, B. Zhang, S. Wang, and H. Tian. 2017. Continental-scale quantification of post-fire vegetation greenness recovery in temperate and boreal North America. Remote Sensing of Environment 199: 277-290. https:// doi.org/10.1016/j.rse.2017.07.022.

Yang, J., H. Tian, B. Tao, W. Ren, S. Pan, Y. Liu, and Y. Wang. 2015. A growing importance of large fires in conterminous United States during 1984-2012. Journal of Geophysical Research 120: 2625-2640. https://doi.org/10.1002/ 2015JG002965.

Zasada, J.C., R.A. Norum, R.M. Van Veldhuizen, and C.E. Teutsch. 1983. Artificial regeneration of trees and tall shrubs in experimentally burned upland black spruce/feather moss stands in Alaska. Canadian Journal of Forest Research 13: 903-913. https://doi.org/10.1139/x83-120.

Zhu, Z., S. Wang, and C.E. Woodcock. 2015. Improvement and expansion of the Fmask algorithm: cloud, cloud shadow, and snow detection for Landsats 4-7, 8, and Sentinel 2 images. Remote Sensing of Environment 159: 269-277. https://doi.org/10.1016/j.rse.2014.12.014. 